\title{
Anti-Yeast Antibody
}

National Cancer Institute

\section{Source}

National Cancer Institute. Anti-Yeast Antibody. NCI Thesaurus. Code C120496.

An antibody produced in response to exposure to yeast. 